\title{
Sidoarjo mud: creating worth from waste
}

\author{
M. F. Nuruddin ${ }^{1}$, A. Fauzi Hasbi ${ }^{1,2}$ \& M. M. Al Bakri Abdullah ${ }^{3}$ \\ ${ }^{1}$ Civil Engineering Department, Universiti Teknologi Petronas, Malaysia \\ ${ }^{2}$ Civil Engineering Department, Politeknik Negeri Lhokseumawe, \\ Indonesia \\ ${ }^{3}$ Civil Engineering Department, Universiti Malaysia Perlis, Malaysia
}

\begin{abstract}
Sidoarjo mud (SM) is generated in considerable amounts from a volcano mud eruption caused by drilling from a gas exploration in the Porong area, Sidoarjo, East Java, Indonesia. The eruption of Sidoarjo mud has damaged the environment and destroyed a significant number of villages. Because of this, a study has been undertaken to convert this material from waste to valuable material in concrete construction. It is noted that Sidoarjo mud is perceived as a material that can be used as a partial cement replacement material called pozzolanic, and also as a source material for geopolymer concrete. Some studies revealed that the overall chemical composition of Sidoarjo mud is similar to Portland cement (OPC), and it is known that the content of $\mathrm{Si}, \mathrm{Al}$ and $\mathrm{Fe}$ in $\mathrm{SM}$ is higher than in OPC. It is also known that the chemical composition $\mathrm{Si}, \mathrm{Al}$ and $\mathrm{Fe}$ are the important elements in concrete especially for the properties development. In this study, it is evident that for conventional concrete, SM has clearly provided increased compressive strength and tensile strength at $10 \%$ replacement of cement weight by $26 \%$ and $9 \%$, respectively.
\end{abstract}

Keywords: Sidoarjo mud, grain size, chemical composition, workability, compressive strength.

\section{Introduction}

Concrete is made from a properly proportioned mixture of hydraulic cement, water, fine and coarse aggregates and, sometimes, chemical or mineral admixture is added as an additive. Currently, the most common hydraulic cement used in construction material is Ordinary Portland Cement (OPC). Annually, the demand for concrete in the construction industry continuously increases, also causing the 
increase in demand for the use of Portland cement. It was estimated that OPC production increased from about from 1.5 billion tons in 1995 to 2.2 billion tons in 2010 [1].

The environmental issues associated with the production of OPC are well known. The quantity of the greenhouse gas, especially $\mathrm{CO}_{2}$, released into the atmosphere due to the calcinations of limestone and combustion of fossil fuel during the manufacture of OPC was approximately one ton for every ton of OPC produced. In addition, the number of energy required to produce OPC is not renewable [2].

The increasing use of OPC persuades the researcher to consider how to reduce the use of OPC in concrete. These efforts include the utilization of supplementary cementing materials (SCMs) such as fly ash (FA), silica fume (SF), ground granulated blast furnace slag (GGBFS), rice-husk ash (RHA) and metakaolin, which can be used as a partial replacement to OPC [2].

\section{Literature review}

Recently, it was found that a new cementitious material called Sidoarjo mud (SM) is being produced abundantly in Indonesia. The material is a flood mud coming out from the earth bowels, which occurred in Sidoarjo, East Java, Indonesia [3]. Figure 1(a) and 1(b) show the SM eruption and impact to the surrounding area. The volume of mud is estimated to be about 100 thousand cubic meters per day, and the mudflow has brought tremendous impact to the surrounding community, especially the economic activity in East Java. The tragedy has also caused evacuation of villages, home/shelter destruction, agricultural and plantation area destruction, more than 15 factories flooded, causing the layoff of more than 1,873 people, educational and infrastructure facilities destruction, inhibition of toll roads between Malang and Surabaya that affect daily activity in Ngoro (Mojokerto) and Pasuruan regions which are the main industrial areas in East Java [4].

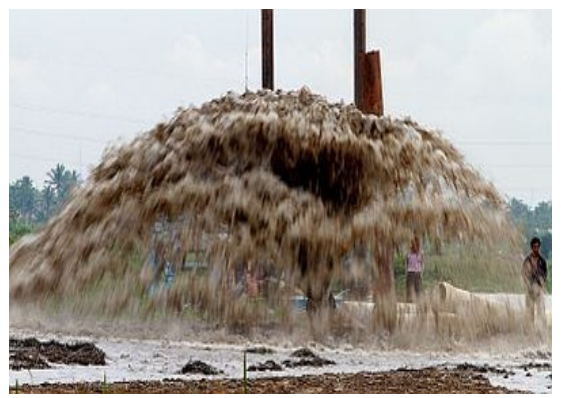

(a)

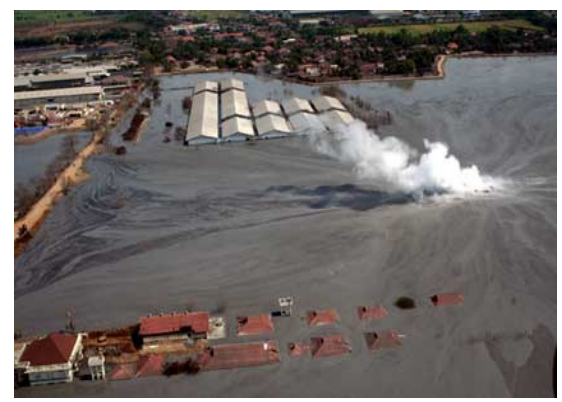

(b)

Figure 1: The SM flood mud coming out from the earth bowels, in Sidoarjo, East Java, Indonesia. (a) The SM eruption; and (b) impact of SM to the surrounding area. 
In addition, the SM is also harmful to public health. The content of heavy metals of $2.565 \mathrm{mg} /$ liter $\mathrm{Hg}$ is alarming compared to the standard which is only $0.002 \mathrm{mg} /$ liter $\mathrm{Hg}$. It leads to respiratory tract infections, skin irritation and cancer. The phenol content can cause rupture of red blood cells (hemolytic), palpitations (cardiac arrhythmia), and renal impairment [5].

Numerous methods have been adopted to stop the SM flow such as dropping thousands of concrete balls into the mud volcano mouth [6], however, this method failed to stop the flow. Another method was to build containment 'basins' or 'ponds' by enclosing areas of land within earth walls, or levees [7]. It was known that this method did help to limit the damage, but it was not a sustainable solution because heavy rain caused the wall to collapse. Finally, it was decided to channel the mud to the Porong River and into the sea (Madura Strait), but the viscosity of the mud hampered the effort. Technical problems arose because the pump did not work well when mud siltation occurred in the pump [8].

Indonesia's environment ministry continues to seek alternatives to prevent the mud ending up in Madura Strait by collecting the mud on the beach and creating new mangrove wetlands or using the mud as a building material for road construction, or using it as a fertilizer mixture [5].

\section{Experimental program}

In this work, fresh SM was dried under the sun and placed in the oven at $100^{\circ} \mathrm{C}$ for 24 hours for further drying [9, 10]. This is important to eliminate the water content, so that smoke can be reduced when calcined. Then, the dry SM was placed in a furnace at a temperature of $500^{\circ} \mathrm{C}$ for five hours. After the calcination period, the mud was allowed to cool down gradually in the furnace until the temperature was similar to the outside or surrounding environment. The mud was then passed in a ball-mill machine for grinding for about two hours, and then sieved to obtain a particle size of less than $100 \mu \mathrm{m}$.

It is expected that the SM has a particle size similar to cement, so that it can act as a microstructure filler at the interfacial transition zone (ITZ). The mud characterization was performed using XRD analyses. Figures 2(a) and 2(b) show the solid SM and the ground SM, respectively.

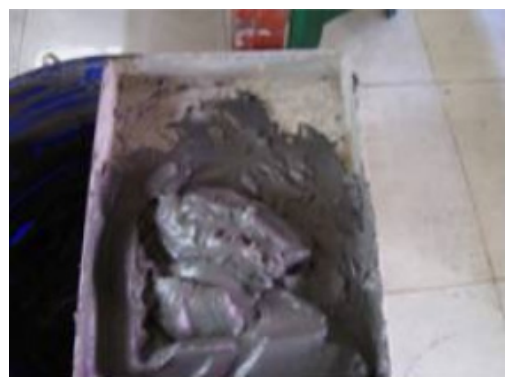

(a)

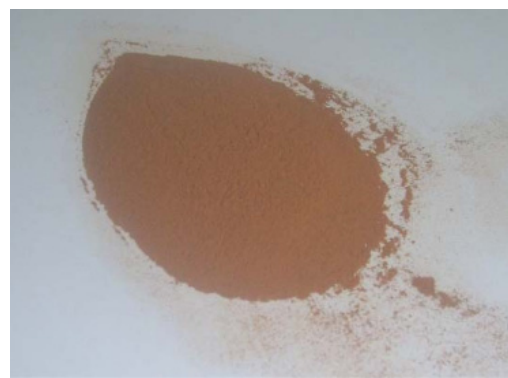

(b)

Figure 2: $\quad$ SM as supplementary cementing material. (a) Solid SM; and (b) grain size SM. 


\section{Results and discussion}

The characterization of material was conducted to understand the material's chemical composition. It was found that the chemical composition of SM is similar to OPC while the particle size of SM is finer than OPC. It is evident that it can be a pozzolan as well as a filler.

Table 1 shows the chemical composition of SM and OPC. The SM is characterized with high silica, alumina and ferric, while OPC is characterized with high lime (calcium) and silica contents. It is evident that the elemental oxide of $\mathrm{SM}$ is quite similar to OPC and the sum of $\mathrm{SiO}_{3}, \mathrm{Al}_{2} \mathrm{O}_{3}$ and $\mathrm{Fe}_{2} \mathrm{O}_{3}$ content is $76.5 \%$ which can be categorized as a class $\mathrm{C}$ of FA.

Table 1: Chemical composition of OPC, FA and SM.

\begin{tabular}{|l|c|c|c|}
\hline Chemical & OPC & FA & SM \\
\hline $\mathrm{SiO}_{2}$ & 20.40 & 24.9 & 38.0 \\
\hline $\mathrm{Fe}_{2} \mathrm{O}_{3}$ & 4.64 & 32.3 & 26.2 \\
\hline $\mathrm{Al}_{2} \mathrm{O}_{3}$ & 2.84 & 10.3 & 12.3 \\
\hline $\mathrm{CaO}$ & 67.70 & 20.9 & 7.46 \\
\hline $\mathrm{Cl}_{2} \mathrm{O}$ & - & - & 3.20 \\
\hline $\mathrm{K}_{2} \mathrm{O}$ & - & 2.8 & 4.77 \\
\hline $\mathrm{SO}_{3}$ & 2.20 & 0.70 & 2.02 \\
\hline $\mathrm{MgO}$ & 2.06 & 2.08 & 1.25 \\
\hline $\mathrm{LOI}$ & 0.16 & 6.02 & 4.80 \\
\hline
\end{tabular}

In terms of Cement Replacement Materials (CRMs) [9, 11], the SM had contributed to concrete properties such as compressive strength and tensile strength. It is shown from Figure 3 that cement replacement by SM is investigated up to $20 \%$ inclusion. In the short term, such as 1 day and 2 days, the compressive strength with $5 \%$ and $10 \%$ SM is significantly more than OPC but $15 \%$ and $20 \%$ $\mathrm{SM}$ is similar. The figure also shows that the increasing trend of compressive strength from 3 days to 28 days of $10 \%$ and $15 \%$ SM is similar with OPC In addition, at long term, after 28 days, the compressive strength of 5\% SM is higher than $10 \%$ SM inclusion. It means that SM can improve the concrete properties in the long term.

It is also evident that increasing compressive strength from $5 \%$ to $20 \% \mathrm{SM}$ follows a parabolic curve with peak compressive strength at $10 \%$ replacement of cement. Compressive strength after $15 \% \mathrm{SM}$ is lower than OPC. It means that the optimum use of SM as cement replacement material in concrete is $10 \%$, although after 28 days there is a possibility that compressive strength of 5\% SM will be higher than $10 \% \mathrm{SM}$ as shown in Figure 4. 


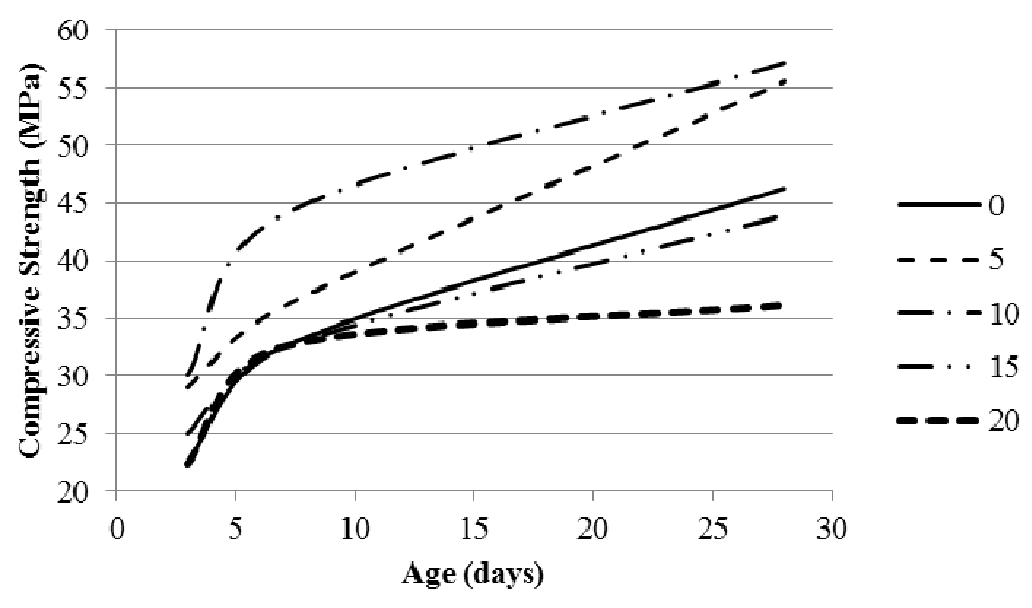

Figure 3: Compressive strength versus time.

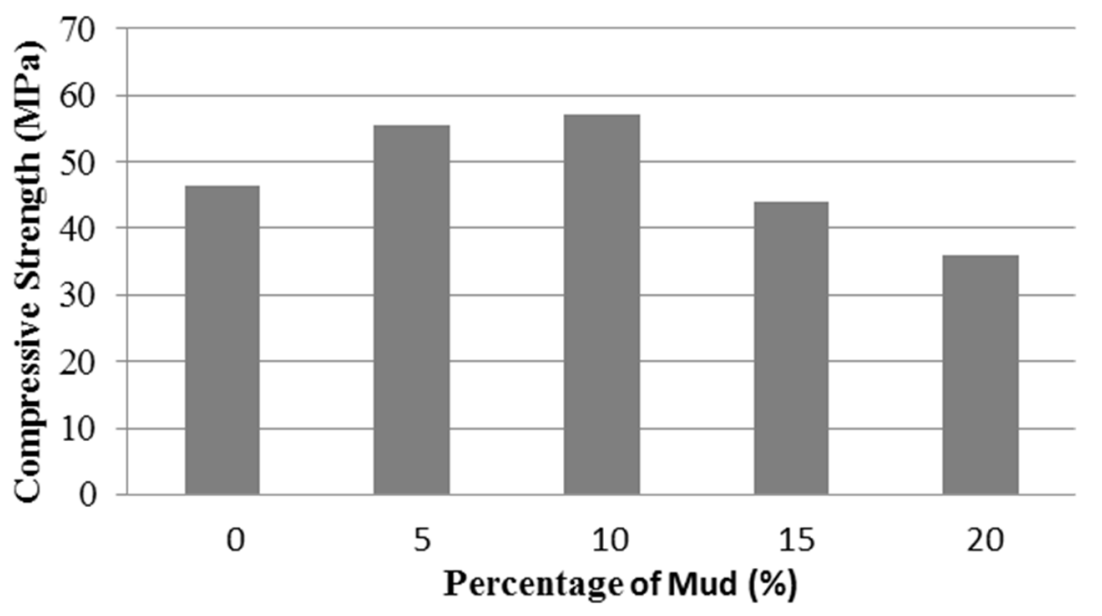

Figure 4: Compressive strength at 28 days.

Figure 5 shows that the tensile strengths of SM at 28 days with percentage of SM up to $20 \%$ replacement are higher than OPC, with the optimum splitting tensile strength at $10 \%$ replacement. However, splitting tensile strength of $20 \% \mathrm{SM}$ is also higher than OPC.

SM porosity at 28 days it is shown in Figure 6. It is evident that porosities of SM with $5 \%$ and $10 \%$ replacement are lower than OPC, but for $15 \%$ and $20 \% \mathrm{SM}$ it is found to be higher than OPC. It means that $5 \%$ and $10 \% \mathrm{SM}$ have less pore in concrete, so that it gives higher compressive strength. On the other hand, $15 \%$ and $20 \%$ SM have more pore, and it gives lower compressive strength. It is generally accepted that the lower porosity will bring higher compressive strength in concrete. 


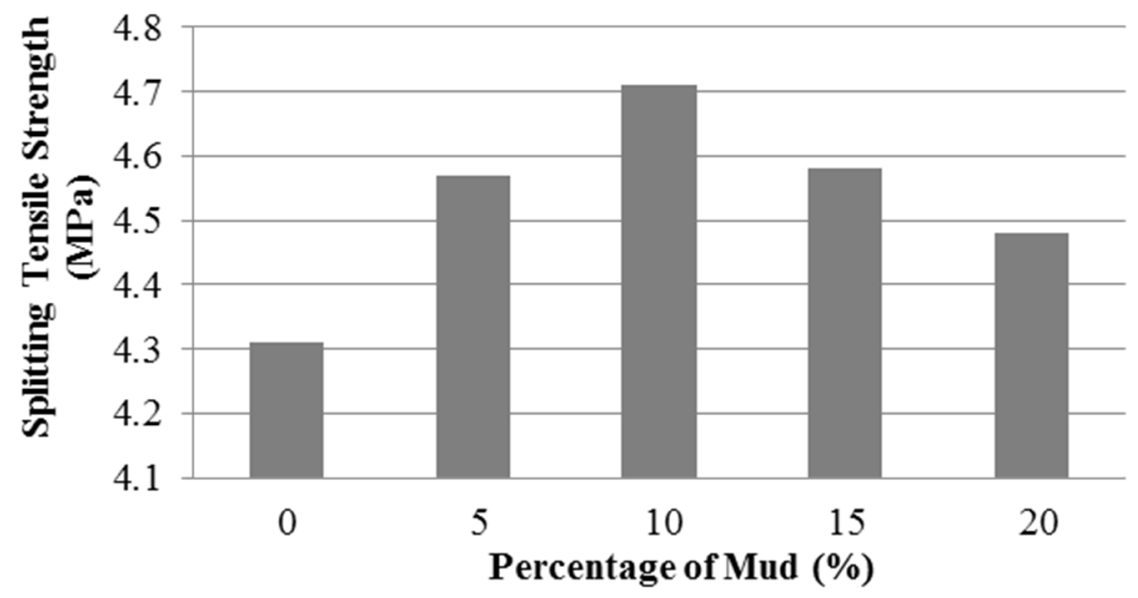

Figure 5: Tensile Strength at 28 days.

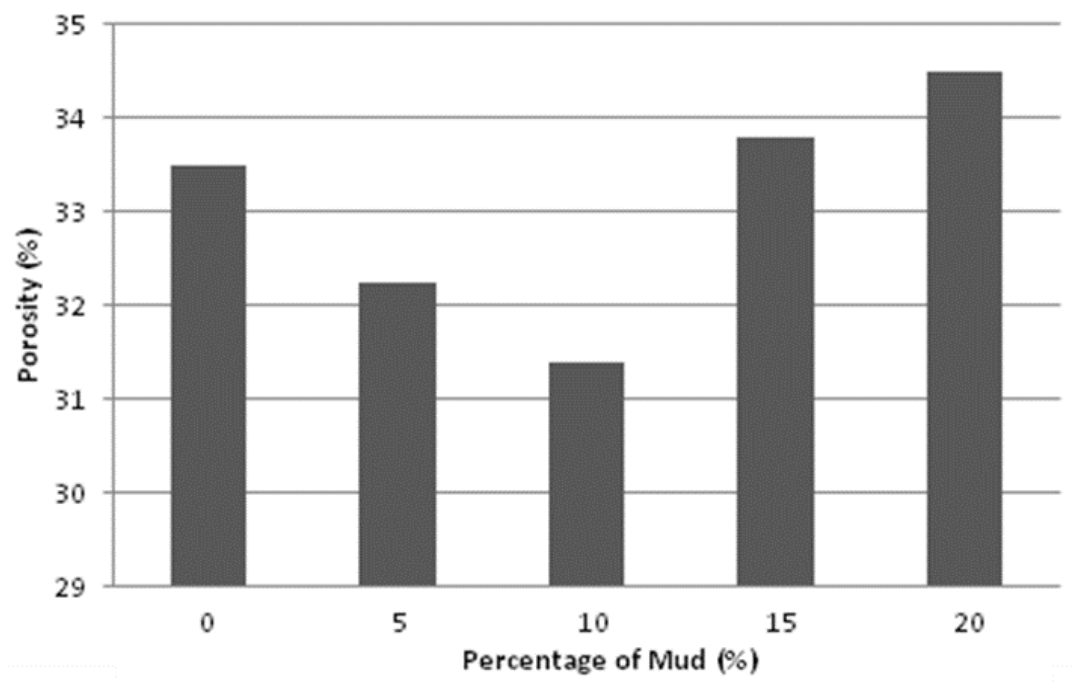

Figure 6: Porosity at 28 days.

\section{Conclusion}

The study to investigate the use of SM in concrete has been done to general properties of concrete and it is confirmed that treated SM from Porong, Sidoarjo, East Java, Indonesia, can be utilized in concrete as a cement replacement material. This material is available in abundance in Sidoarjo which, if not utilized, will have an adverse environmental impact. 


\section{References}

[1] Malhotra, V.M., Making concrete "greener" with fly ash. ACI's Concrete International, 1999. 21(5): pp. 61-66.

[2] Dustan, E.R., How does pozzolanic reaction make concrete "green"? World of Coal Ash (WOCA) Conference, in Denver, CO, USA, 2011.

[3] Davies, R.J., et al., Probabilistic longevity estimate for the LUSI mud volcano, East Java. Journal of the Geological Society, 2011. 168: pp. 517523.

[4] Badan Penanggulangan Lumpur Sidoarjo (BPLS). 2010a. Rencana Strategis 2010-2014 (Strategic Plan 2010-2014). Surabaya: Sidoarjo Mudflow Mitigation Agency, vii p. 156 2010b. "Kemajuan Penanggulangan Lumpur Sidoarjo (Sidoarjo Mudflow Mitigation Progress).” Surabaya: Sidoarjo Mudflow Mitigation Agency, p. 21.

[5] Pohl, C., Lapindo Brantas and the mud volcano Sidoarjo, Indonesia. Friends of the Earth International, 2007.

[6] Brief halt for Indonesia mud flow. BBC News. March 20 2007; East Java mudflow stops for 35 minutes. The Jakarta Post, March 192007.

[7] Govt weighs options for battling the sludge, Indra Harsaputra, The Jakarta Post, May 292007.

[8] Sidoarjo sludge starts to be dumped into the sea. Indahnesia.com, Oct 16 $2006 \mathrm{http}: / /$ news.indahnesia.com/item/200610166/sidoarjo_sludge_starts to_be_dumped_into_the_sea.php (Retrieved April 10 2007).

[9] Nuruddin, M.F., et al., Sidoarjo mud: a potential cement replacement material. Civil Engineering Dimension, 2010. 12(1): pp. 18-22.

[10] Antoni, et al., Influence of heat treatment temperature, particle fineness and replacement ratio of sidoarjo mud as pozzolanic material. The 5th International Conference of Asian Concrete Federation, 2012.

[11] Hardjito, D., et al., Pozzolanic Activity Assessment of LUSI (LUmpur SIdoarjo) Mud in Semi High Volume Pozzolanic Mortar. Materials, 2012. 5(9): pp. 1654-1660. 